\title{
Effects of dietary energy level on the performance and carcass characteristics of lambs
}

\section{Teores de energia na ração sobre o desempenho e características de carcaça de cordeiros confinados}

\author{
Walter Piola Junior ${ }^{1}$; Filipe Alexandre Boscaro de Castro $^{2}$; Valter Harry Bumbieris \\ Júnior ${ }^{2}$; Leandro das Dores Ferreira da Silva²; Carolina Amália de Souza Dantas \\ Muniz $^{2}$; Edson Luis de Azambuja Ribeiro ${ }^{2 *}$
}

\section{Highlights:}

The presentation of cuts favors the commercialization of sheep meat products.

Production efficiency can be determined by the energy density of the animal feed.

Carcass yield is partly determined by the amount of fat produced.

Higher dietary energy contents favor increases in carcass weight.

\begin{abstract}
The objective of this study was to evaluate the influence of ration energy levels on the performance and carcass characteristics of confined lambs. Four energy levels were evaluated: 2.00; 2.28; 2.54, and $2.80 \mathrm{Mcal}$ of $\mathrm{ME} \mathrm{kg}^{-1} \mathrm{DM}$, with the last content being recommended by the National Research Council [NRC] (2007) for daily weight gains of $300 \mathrm{~g}$. Twenty-four crossbred Ile de France ram lambs (six per treatment) at $240.0 \pm 9.6$ days of age and $26.6 \pm 3.8 \mathrm{~kg}$ body weight, fed with isoprotein diets $\left(158 \mathrm{~g} \mathrm{~kg}^{-1}, \mathrm{CP}\right)$ were used. The confinement lasted 57 days. Final body weight, cold carcass weight, and cold carcass yield were linearly and positively influenced by diet energy content. Food intake, average daily weight gain, and feed conversion were quadratically influenced by energy level, where the highest averages were observed under diets containing between 2.54 and $2.80 \mathrm{Mcal}$. In percentage terms, the main carcass cuts (leg and shoulder) were not influenced by diet energy level. In terms of the shoulder tissue composition, it was observed that bone content decreased linearly, fat content increased quadratically, and muscle content was not affected by the energy content of the diet. It was concluded that diets with higher energy densities lead to the production of heavier carcasses with higher yields, as well as increased weight gains. Optimal diets should therefore contain between 2.54 and $2.80 \mathrm{Mcal}$ of ME $\mathrm{kg}^{-1} \mathrm{DM}$.
\end{abstract}

Key words: Commercial cuts. Fat. Sheep. Tissue composition. Yield.

\section{Resumo}

Objetivou-se avaliar a influência de diferentes teores energéticos na ração sobre o desempenho e características de carcaças de cordeiros confinados. Avaliaram-se quatro teores energéticos: 2,00; 2,28; 2,54 e 2,80 Mcal de EM kg-1 MS, sendo o último teor o recomendado pelo NRC (2007) para ganhos

\footnotetext{
1 Pesquisador, Agência de Defesa Agropecuária do Paraná, ADAPAR, Londrina, PR, Brasil. E-mail: piolajr@gmail.com

2 Profs. Drs., Departamento de Zootecnia, Universidade Estadual de Londrina, UEL, Londrina, PR, Brasil. E-mail: fabcastro@uel. br,jrbumbieris@uel.br; leandro@uel.br; muniz@uel.br; elar@uel.br

* Author for correspondence
} 
diários de $300 \mathrm{~g}$. Foram utilizados 24 cordeiros inteiros com 240,0 $\pm 9,6$ dias de idade e $26,6 \pm 3,8 \mathrm{~kg}$ de peso corporal, seis por tratamento, mestiços Ile de France, alimentados com rações isoprotéicas (158 $\left.\mathrm{g} \mathrm{kg}^{-1}, \mathrm{~PB}\right)$. O confinamento durou 57 dias. O peso corporal final e de carcaça fria, bem como o rendimento de carcaça fria, apresentaram comportamento linear positivo de acordo com os teores de energia. Já o consumo de alimentos, o ganho médio diário de peso e a conversão alimentar, foram influenciados de forma quadrática pelos teores de energia, onde as melhores médias foram observadas para rações contendo entre 2,54 e 2,80 Mcal. Em termos percentuais, os principais cortes da carcaça (pernil e paleta) não foram influenciados pelos teores energéticos das rações. Na composição tecidual da paleta, observou-se que o teor de ossos diminuiu linearmente, o de gordura aumentou de forma quadrática e o de músculo não foi afetado pelos teores de energia da ração. Conclui-se que dietas com maiores densidades energéticas proporcionam a produção de carcaças mais pesadas e com maiores rendimentos e para melhores ganhos de peso as rações devem conter entre 2,54 e 2,80 Mcal de EM kg-1 MS.

Palavras-chave: Composição tecidual. Cortes comerciais. Gordura. Ovinos. Rendimento.

\section{Introduction}

Carcasses are the result of an individual biological process influenced by genetic, ecological, and management factors, differing from one another by their quantitative and qualitative characteristics. Knowledge and description of these characteristics are of great importance for both the commercialization and production of carcasses (Osório, Osório, Fernandes, \& Vargas, 2014).

Although carcasses can be sold as a single piece, they are often divided into commercial cuts, which can influence the presentation of the product, making this an important factor in marketing. The cutting system, in addition to allowing differentiated pricing between different parts of the carcass, allows rational use and avoids food waste (Alves et al., 2003; Maysonnave et al., 2017). The proportion of the carcass represented by each of these cuts is an important index for assessing their quality.

Several factors can affect the carcass and cuts yield, especially diet, which is unquestionably one of the most important determinants. The energy density of the diet has a particularly large influence. Among all the components of animal diets, energy has received special attention because it is fundamentally important in the functioning of vital organs, in the activity and renewal of cells and processes, and in nutrient use (Puppel \& Kuczynska, 2016).
Energy plays a critical role in the deposition of fat on the carcass. However, excessive fat accumulation is generally unwanted by consumers, in addition to making animal diets more expensive. Therefore, energy must be used with maximum efficiency within a rational production system. Excess accumulated fat means that waste occurs in the toilet of the carcass and in the preparation of cuts for sale and consumption (Constantino, Koritiaki, Fernandes, \& Ribeiro, 2018). On the contrary, when animals are slaughtered at the same age, a lack of fat on the carcass signifies insufficient energy input, indicating production inefficiency (Araújo et al., 2017).

Thus, in view of the need to improve production efficiency as well as carcass quality, the objective of this study was to evaluate the performance and carcass characteristics of lambs subjected to different levels of energy in the feed.

\section{Material and Methods}

The experiment was conducted at the Farm School and at the Animal Food and Nutrition Laboratory of the Animal Sciences Department, Agrarian Sciences Center, Londrina State University (UEL), Londrina, PR, Brazil. The experimental procedures were approved by the UEL Ethics Committee on Animal Experimentation (CEEA), registered under No. 60/10. A completely randomized design was used, 
with four treatments and six replicates per treatment. The treatments corresponded to different levels of metabolizable energy: $2.00 ; 2.28 ; 2.54$; and 2.80 Mcal of ME kg ${ }^{-1} \mathrm{DM}$. The last treatment represented the diet metabolizable energy recommended by the NRC (2007) for eight-month-old sheep aiming for daily gains of $300 \mathrm{~g}$.

After an adaptation period of 15 days, the animals were weighed to obtain their initial weights before being randomly distributed among the treatments. Confinement was carried out in a fold with a raised and slatted floor, and two animals were housed per pen. Twenty-four crossbred Ile de France ram lambs at $240.0 \pm 9.6$ days of age and weighing 26.6 $\pm 3.8 \mathrm{~kg}$ were used, with six lambs per treatment. The total rations, composed of sorghum silage and concentrate, were isoproteins (Table 1) and were supplied twice daily (at $8 \mathrm{~h} 00$ and 17h00).

Table 1

Composition of experimental diets $\left(\mathrm{g} \mathrm{kg}^{-1} \mathrm{DM}\right)$

\begin{tabular}{ccccc}
\hline & \multicolumn{4}{c}{ Metabolizable energy content (Mcal kg-1 DM) } \\
\cline { 2 - 4 } Ingredients & $\mathbf{2 . 0 0}$ & $\mathbf{2 . 2 8}$ & $\mathbf{2 . 5 4}$ & $\mathbf{2 . 8 0}$ \\
\cline { 2 - 4 } & \multicolumn{4}{c}{ Percent composition } \\
\cline { 2 - 4 } & 807.5 & 600.0 & 400.0 & 200.0 \\
Sorghum silage & 4.3 & 194.2 & 389.7 & 571.3 \\
Grain corn & 168.9 & 174.2 & 166.3 & 165.8 \\
Soybean meal & 0.0 & 12.8 & 23.4 & 36.5 \\
Soybean oil & 10.0 & 10.0 & 10.0 & 10.0 \\
Mineral salt & 0.5 & 2.6 & 4.7 & 6.7 \\
Limestone & 0.0 & 0.0 & 0.0 & 5.0 \\
Sodium bicarbonate & 5.8 & 5.2 & 4.9 & 4.6 \\
Dicalcium phosphate & 3.0 & 1.0 & 1.0 & 0.1 \\
Urea & & Chemical composition & 770.7 \\
Components & 401.4 & 527.3 & 648.6 & 770.8 \\
Dry matter & & 645.2 & 708.4 & 158.0 \\
Total digestible nutrients & 576.8 & 157.7 & 157.6 & 70.0 \\
Crude protein & 157.5 & 44.8 & 56.3 & 219.0 \\
Ether extract & 31.3 & 476.3 & 347.8 & \\
Neutral detergent fiber & 608.9 & &
\end{tabular}

${ }^{1}$ In Natural Matter.

The amount of feed and any leftovers were weighed daily and were adjusted according to how much the animals consumed so that approximately $10 \%$ of the food given was uneaten. The dry matter $(\mathrm{DM})$, crude protein $(\mathrm{PB})$, ether extract (EE), and neutral detergent fiber (NDF) contents were determined for samples of the rations provided (Table 1) and leftovers according to the methodology described by Silva and Queiroz (2002). The total digestible nutrients (TDN) content was estimated according to the methodology outlined by Kearl (1982).

Animals were weighed weekly, after a previous fasting period from solids of 18 hours, to determine the average daily gain. After 57 days, the animals were fasted from solids for 18 hours and weighed to 
obtain body weight at slaughter. The animals were slaughtered in a commercial abattoir. Carcasses were weighed immediately after slaughter to obtain the hot carcass weight, and after refrigeration at $2^{\circ} \mathrm{C}$ for 24 hours in a chilling chamber to obtain the cold carcass weight, and after to obtain the carcass yield and chilling losses.

Carcasses were divided longitudinally at the midline into two antimeres, and the left part was then sectioned into five anatomical regions (ColomerRocher, Morand-Fehr, Kirton, Delfa-Belenguer, \& Sierra-Alfranca, 1988). Such regions included: 1) Leg; includes the bone base that covers the iliac region (ileum), ischium, pubis, sacral vertebrae, the first two coccygeal vertebrae, femur, tibia, and tarsos, obtained by cutting perpendicular to the column between the last lumbar vertebra and the first sacral, 2) Loin; comprises the region of the lumbar vertebrae, obtained perpendicular to the spine between the 13th dorsal-first lumbar vertebra and the last lumbar-first sacral, 3) Ribs; includes the 13 thoracic vertebrae, with the ribs corresponding to the sternum, 4) Shoulder; region comprising the scapula, humerus, radius, ulna, and carpus, and 5) Neck; refers to the seven cervical vertebrae, obtained by an oblique cut between the seventh cervical and the first thoracic. The left shoulder was dissected with the aim of obtaining the weights and proportions of the bone, muscle, and fat (Osório et al., 2014).

The data were subjected to analysis of variance, with a mathematical model including the fixed effect of treatment (energy content). In addition, polynomial regressions were carried out according to the four energy levels, using the statistical package Statistical Analysis System Institute [SAS] (2016). The level of significance was 5\%.

\section{Results and Discussion}

There was a significant effect of energy content on the animals' performance (Table 2). For slaughter weight, there was a growing linear effect of energy content in the feed, with values ranging from 32.55 to $43.65 \mathrm{~kg}$.

\section{Table 2}

Estimated averages of the performance characteristics of lambs fed different amounts of metabolizable energy

\begin{tabular}{|c|c|c|c|c|c|c|c|}
\hline \multirow[t]{2}{*}{ Variable } & \multicolumn{4}{|c|}{$\begin{array}{l}\text { Metabolizable energy content } \\
\left.\text { (Mcal kg } \mathrm{kg}^{-1} \mathrm{DM}\right)\end{array}$} & \multirow[t]{2}{*}{ Regression $^{1}$} & \multirow{2}{*}{$\mathbf{R}^{2}$} & \multirow{2}{*}{$\begin{array}{l}\text { CV } \\
(\%)\end{array}$} \\
\hline & 2.00 & 2.28 & 2.54 & 2.80 & & & \\
\hline Initial body weight, $\mathrm{kg}$ & 27.03 & 26.06 & 26.45 & 27.10 & $\tilde{y}=26.66$ & - & 15.41 \\
\hline Body weight at slaughter, $\mathrm{kg}$ & 32.55 & 37.33 & 42.22 & 43.65 & $\hat{y}=3.31+14.86 x$ & 0.95 & 13.80 \\
\hline Empty body weight, kg & 25.98 & 31.04 & 36.48 & 38.09 & $\hat{y}=-6.01+16.22 x$ & 0.95 & 15.04 \\
\hline Average daily gain, $\mathrm{kg}$ & 0.10 & 0.22 & 0.28 & 0.29 & $\hat{y}=-2.52+2.07 x-0.38 x^{2}$ & 1.00 & 23.78 \\
\hline Dry matter consumption ( $\% \mathrm{BW})$ & 4.15 & 4.98 & 5.19 & 4.77 & $\hat{y}=-21.62+21.51 x-4.32 x^{2}$ & 0.76 & 5.94 \\
\hline Food conversion ratio & 12.83 & 8.76 & 6.57 & 5.56 & $\hat{y}=86.87-56.98 x+9.99 x^{2}$ & 0.93 & 12.06 \\
\hline
\end{tabular}

$\mathrm{R}^{2}=$ coefficient of determination, $\mathrm{CV}=$ coefficient of variation.

$1=$ significance value considered: $5 \%$.

For average daily gain, a quadratic effect of energy content was observed. Through the regression equation obtained for this variable, the highest average daily gain was obtained with 2.72 Mcal of ME kg-1 DM; a content close to the maximum given in the present study. This probably reflects the consumption of dry matter, which also showed a quadratic trend.

In general, the behavior of the data obtained for animal performance is in agreement with that cited 
in other studies evaluating different dietary energy levels (Alves et al., 2003; Pereira et al., 2010; Piola et al., 2009a,b). Many studies have observed that diets with higher energy levels provide greater weight gains, higher slaughter weights, and increased carcass weights. Similarly, when the slaughter weight is predetermined, the time required for confinement, or for fattening, is decreased at higher energy levels (Piola et al., 2009a,b).

The weight gain of animals receiving $2.8 \mathrm{Mcal}$ of ME was $0.290 \mathrm{~kg} \mathrm{day}^{-1}$, which is fully in-line with the gain $\left(0.300 \mathrm{~kg} \mathrm{day}^{-1}\right)$ established by the NRC (2007). This result demonstrated that the diets used were adequate in their composition and quality, and that the animals had genetic potentials consistent with the expected gain. When diets are formulated for a given weight gain and the results are less than expected, the diets were probably less degradable and/or digestible, or animals had less potential to use the food provided. This was the case in the study by Mahgoub, Lu and Early (2000), in which diets containing 2.4, 2.5, and 2.7 Mcal of ME kg-1 DM for growing sheep were evaluated, and weight gains of $0.090,0.115$, and $0.147 \mathrm{~kg} \mathrm{day}^{-1}$, respectively, were observed.

Consumption in relation to body weight and metabolic weight showed quadratic effects with increases in energy levels, peaking at 2.49 Mcal of $\mathrm{ME} \mathrm{kg} \mathrm{kg}^{-1} \mathrm{DM}$ and 2.50 Mcal of $\mathrm{ME} \mathrm{kg} \mathrm{kg}^{-1} \mathrm{DM}$, respectively. These values demonstrate that the energy content of the feed has a great influence on the performance of the animals, because animals consume food to meet their nutrient requirements. If the concentration of nutrients increases in the food offered, with a concomitant improvement in quality, there is a tendency for intake to increase, and if the concentration continues to increase, there is a subsequent decrease in consumption, as the animal needs to consume less to meet the requirements. On the contrary, when the energy concentration is low, the effect of rumen repletion controls consumption (Van Soest, 1965; Detmann, Gionbelli, \& Huhtanen, 2014). In the present study, the caloric density of the feed was the determining factor that limited voluntary consumption in animals subjected to more energetic diets.

The consumption of dry matter observed in the present study $(4.15 \%$ to $5.19 \% \mathrm{PV})$ was within the recommendations of the NRC (2007), which varies from 4 to $6 \%$ of body weight for the weights and daily gains presented. These results demonstrate that the lambs were of good productive potential, and that the rations used were of adequate quality. The results observed for dry matter consumption are close to those found by Mahgoub et al. (2000) and Pereira et al. (2010), who used diets with energy levels close to those used in the present study.

For feed conversion ratio, although a quadratic effect was observed, the peak was at $2.85 \mathrm{Mcal}$ of energy, which is greater than the highest value used in the present study. Therefore, there was an improvement in conversion with increasing energy density in the diet, and the optimal ratio observed was 5.56 for the treatment with $2.80 \mathrm{Mcal}$ of energy. When diets have higher fiber contents and/or less degradability and digestibility, there is a tendency for feed conversion to worsen. This was observed in the study by Alves et al. (2003), which found a conversion ratio of 7.0 using $2.83 \mathrm{Mcal}$ of DM, and in the study by Mahgoub et al. (2000), which used 2.83 Mcal of ME and observed a 7.3 feed conversion ratio.

The efficiency of energy use tends to be lower for bulky diets, as there is a greater loss of heat due to the production of acetate and methane (Chamkaur, Nishida, Phosphasal, \& Sommart, 2015). This explains the observation that the best feed conversion ratios occur for diets with more energy, that is, with a lower proportion of roughage.

Hot and cold carcass weights (Table 3) are a direct reflection of slaughter weights, and treatments with the highest dietary energy contents produced the highest averages.

The chilling loss (Table 3) was not influenced ( $>0.05$ ) by treatment, probably due to the high 
coefficient of variation observed. According to Cartaxo et al. (2011), more energetic diets promote fewer chilling losses because there is usually a greater accumulation of fat, which works as a thermal insulator. In the present study, the numerical values for losses were lower for more energetic diets.

Table 3

Estimated averages of carcass characteristics of lambs fed four different amounts of metabolizable energy

\begin{tabular}{|c|c|c|c|c|c|c|c|}
\hline \multirow[t]{2}{*}{ Variable } & \multicolumn{4}{|c|}{$\begin{array}{l}\text { Metabolizable energy content } \\
\text { (Mcal kg } \mathrm{kg}^{-1} \text { DM) }\end{array}$} & \multirow[t]{2}{*}{ Regression $^{1}$} & \multirow[t]{2}{*}{$\mathbf{R}^{2}$} & \multirow{2}{*}{$\begin{array}{l}\text { CV } \\
(\%)\end{array}$} \\
\hline & 2.00 & 2.28 & 2.54 & 2.80 & & & \\
\hline Hot carcass weight, $\mathrm{kg}$ & 15.73 & 18.30 & 21.35 & 22.25 & $\hat{y}=-1.60+8.76 x$ & 0.96 & 14.60 \\
\hline Cold carcass weight, kg & 14.63 & 17.15 & 20.32 & 21.15 & $\hat{y}=-2.85+8.82 x$ & 0.95 & 15.71 \\
\hline Chilling loss (\%) & 7.29 & 6.58 & 4.88 & 4.87 & $\tilde{y}=5.91$ & - & 42.88 \\
\hline Biological yield (\%) & 60.84 & 58.99 & 58.72 & 58.28 & $\tilde{y}=59.21$ & - & 4.70 \\
\hline Hot carcass yield (\%) & 48.50 & 49.03 & 50.58 & 50.78 & $\tilde{y}=49.72$ & - & 3.78 \\
\hline Cold carcass yield (\%) & 44.91 & 45.83 & 48.10 & 48.30 & $\hat{y}=35.17+4.84 x$ & 0.91 & 4.00 \\
\hline
\end{tabular}

$\mathrm{R}^{2}=$ coefficient of determination, $\mathrm{CV}=$ coefficient of variation

$1=$ significance value considered: $5 \%$.

Only the cold carcass yield differed between treatments (Table 3), with a linear increase in yield with increasing dietary energy. Among the probable factors that interfered in this result, we can highlight the fiber contents of the diets, as the more energetic diets contained less fiber content (Table 1). More fibrous diets take longer to leave the rumen-reticulum, in addition to promoting greater development of the digestive tract. Even if the animals were fasted before slaughter, this period was not long enough for the complete emptying of the digestive tract. From the data presented in Table 2, it is possible to calculate the contents (food still retained) of the digestive tracts (content in the digestive tract $=$ body weight at slaughter - empty body weight), which ranged from $6.57 \mathrm{~kg}$ to 5.56 $\mathrm{kg}$, or from $20.18 \%$ to $12.74 \%$ of body weight at slaughter, for treatments with 2.00 and $2.80 \mathrm{Mcal}$ of energy. In addition, carcasses with greater fat deposition generally present higher yields.

There was a positive linear effect $(p<0.05)$ of energy level on the weight of the cuts, except for the neck (Table 4), with the highest values observed in treatments with more energy. These results are a direct reflection of the higher carcass weights obtained from these treatments. The weights of the cuts varied similarly to those in the study by Gonzaga et al. (2006), in which higher weights of cuts were associated with the highest energy contents.

In terms of the yields of cuts as proportions of the total carcass weight (Table 4), there was significance for loin (cubic effect), which peaked at $15.36 \%$ for feed with $2.61 \mathrm{Mcal}$, and reached its minimum at $11.60 \%$ with 2.12 Mcal. Rib yield was also influenced by the treatments (increasing linear effect). According to Mattos et al. (2006), increases in the weight and proportion of the ribs occurs because it is a region of the animal's body in which fat accumulates at a higher speed, thus increasing in weight as the animal grows or is fed a more energetic ration. The behavior of cut yield data in the present study is similar to that in the studies by Gonzaga et al. (2006), Ribeiro et al. (2010), and Pereira et al. (2010). 
Table 4

Estimated average cut weights (kg) and cut weights as a percentage of total carcass weight (\%) of lambs fed different amounts of metabolizable energy

\begin{tabular}{|c|c|c|c|c|c|c|c|}
\hline \multirow[t]{2}{*}{ Variable } & \multicolumn{4}{|c|}{$\begin{array}{c}\text { Metabolizable energy content } \\
(\text { Mcal kg-1 DM) }\end{array}$} & \multirow[t]{2}{*}{ Regression $^{1}$} & \multirow{2}{*}{$\mathbf{R}^{2}$} & \multirow{2}{*}{$\begin{array}{l}\text { CV } \\
(\%)\end{array}$} \\
\hline & 2.00 & 2.28 & 2.54 & 2.80 & & & \\
\hline Half-carcass, $\mathrm{kg}$ & 7.03 & 8.2 & 9.52 & 10.53 & $\hat{y}=-1.92+4.47 x$ & 1 & 17.9 \\
\hline Shoulder, kg & 1.42 & 1.81 & 2.03 & 2.07 & $\hat{y}=-0.23+0.86 x$ & 0.88 & 16.85 \\
\hline Shoulder (\%) & 20.54 & 22.37 & 21.30 & 19.83 & $\tilde{y}=21.01$ & - & 13.94 \\
\hline Leg, kg & 2.51 & 2.75 & 3.16 & 3.4 & $\hat{y}=0.14+1.17 x$ & 0.99 & 14.54 \\
\hline $\operatorname{Leg}(\%)$ & 35.75 & 33.85 & 33.34 & 32.81 & $\tilde{y}=33.94$ & - & 5.81 \\
\hline Loin, kg & 0.88 & 1.05 & 1.44 & 1.4 & $\hat{y}=-0.67+0.78 x$ & 0.84 & 22.59 \\
\hline Loin (\%) & 12.50 & 12.50 & 15.15 & 13.28 & $\begin{array}{c}\hat{y}=855.39-1089.15 x+ \\
464.55 x^{2}-65.35 x^{3}\end{array}$ & 1 & 9.26 \\
\hline Ribs, kg & 1.46 & 1.88 & 2.24 & 2.7 & $\hat{y}=-1.59+1.52 x$ & 1 & 27.14 \\
\hline Ribs (\%) & 20.80 & 22.70 & 23.48 & 25.08 & $\hat{y}=10.70+5.12 x$ & 0.97 & 9.86 \\
\hline Neck, kg & 0.76 & 0.7 & 0.64 & 0.95 & $\tilde{y}=0.76$ & - & 37.92 \\
\hline Neck (\%) & 10.41 & 8.59 & 6.73 & 8.99 & $\tilde{y}=8.68$ & - & 32.60 \\
\hline
\end{tabular}

$\mathrm{R}^{2}=$ coefficient of determination, $\mathrm{CV}=$ coefficient of variation.

$1=$ significance value considered: $5 \%$.

Proportional shoulder, leg, and neck yields were not influenced by treatment. Thus, it can be said that these cuts, or regions of the carcass, developed harmoniously with the development of the animal. That is, the cuts remained similar in proportion, regardless of whether the carcass was larger or smaller. This was also observed in the study by Silva, Pires, Zeppenfeld and Chagas (2000), which concluded that the proportions of the main cuts do not change in relation to the carcass weight.

Lower values than those observed in the present study were reported by Furusho-Garcia, Pérez, Bonarurio, Lima and Quintão (2004) when evaluating diets containing $2.8 \mathrm{Mcal}$ of ME $\mathrm{kg}^{-}$ ${ }^{1} \mathrm{DM}$ composed of $80 \%$ concentrate in Santa Inês sheep slaughtered at $35 \mathrm{~kg}$ body weight. The aforementioned study reported yields of 14.95, 7.30 , and $27.55 \%$, for the shoulder, loin, and leg, respectively. In general, the leg produces the highest yields, as it has the greatest amount of muscle tissue in comparison to the other cuts.
In quantitative terms $(\mathrm{kg})$, the shoulder bone and muscle tissues increased linearly with increasing dietary energy content (Table 5). This is due to the fact that the shoulder yield itself increased linearly. On the contrary, the amount of fat in the shoulder increased quadratically, with the largest amount of fat being found $(0.26 \mathrm{~kg})$ under an energy content of 2.54 Mcal of ME kg-1 DM. However, in proportional terms (\%), while the bone content decreased under higher dietary energy contents, the muscle content remained constant, with an average of $67.9 \%$. There was a quadratic effect of energy level on the proportion of fat, similarly to what was observed for the quantity of fat in kilos. The variation in the amount and percentage of fat is a direct reflection of the variation in the energy densities of the diets up to the level of $2.54 \mathrm{Mcal}$ of $\mathrm{ME} \mathrm{kg}^{-1} \mathrm{DM}$. The decreases in the fat values under the highest energy level (2.80 Mcal of ME $\left.\mathrm{kg}^{-1} \mathrm{DM}\right)$ compared to under the $2.54 \mathrm{Mcal}$ of $\mathrm{ME} \mathrm{kg}^{-1} \mathrm{DM}$ level cannot be explained logically. 
Table 5

Estimated average weights (kg) and percentages of bone, muscle, and fat in the shoulder of lambs fed four different amounts of energy

\begin{tabular}{|c|c|c|c|c|c|c|c|}
\hline \multirow[t]{2}{*}{ Variable } & \multicolumn{4}{|c|}{$\begin{array}{l}\text { Metabolizable energy content } \\
\left.\text { (Mcal kg } \mathrm{kg}^{-1} \mathrm{DM}\right)\end{array}$} & \multirow[t]{2}{*}{ Regression $^{1}$} & \multirow[t]{2}{*}{$\mathbf{R}^{2}$} & \multirow{2}{*}{$\begin{array}{l}\text { CV } \\
(\%)\end{array}$} \\
\hline & 2.00 & 2.28 & 2.54 & 2.80 & & & \\
\hline Bones, kg & 0.33 & 0.37 & 0.40 & 0.42 & $\hat{y}=0.10+0.12 x$ & 1.00 & 14.38 \\
\hline$\%$ & 23.51 & 20.67 & 20.02 & 20.52 & $\hat{y}=30.84-4.05 x$ & 0.60 & 10.31 \\
\hline Muscle, kg & 0.98 & 1.22 & 1.36 & 1.40 & $\hat{y}=0.09+0.56 x$ & 0.90 & 17.39 \\
\hline$\%$ & 69.14 & 67.49 & 67.27 & 67.65 & $\tilde{y}=67.89$ & - & 2.89 \\
\hline Fat, kg & 0.11 & 0.22 & 0.26 & 0.24 & $\hat{y}=-2.74+2.31 x-0.45 x^{2}$ & 1.00 & 32.81 \\
\hline$\%$ & 7.35 & 11.84 & 12.71 & 11.83 & $\hat{y}=-107.51+94.67 x-18.60 x^{2}$ & 0.99 & 23.70 \\
\hline
\end{tabular}

$\mathrm{R}^{2}=$ coefficient of determination, $\mathrm{CV}=$ coefficient of variation

$1=$ significance value considered: $5 \%$.

The percentages of tissues found in the present study for the heaviest slaughtered lambs are very close to those obtained in the study by Constantino et al. (2018), who assessed several categories of sheep, and in the study by Grandis et al. (2016), who assessed Santa Inês lambs slaughtered at 38 $\mathrm{kg}$. The means cited by the authors were $22.93 \%$, $63.91 \%$, and $13.51 \%$ for bones, muscles, and fat, respectively. Among the tissues that make up the carcass, the fat content is the most variable and can be influenced by the energy content of the diet, age, sex, and genotype of the animals (Cartaxo et al., 2011; Constantino et al., 2018). Animals that received more energetic diets, which were older females and castrated males, tended to produce carcasses with higher levels of fat (Constantino et al., 2018). When the levels of fat increase in the carcass, the amounts of muscle and bone decrease. Piola et al. (2009b) observed negative correlations between fat and muscle, ranging from -0.43 to -0.71 , and between fat and bones, ranging from -0.22 to -0.55 , for different commercial cuts in carcasses of Texel crossbred lambs slaughtered at $32 \mathrm{~kg}$.

\section{Conclusions}

For best performance (weight gain, food consumption, and feed conversion), rations must contain at least $2.50 \mathrm{Mcal}$ of $\mathrm{ME} \mathrm{kg}^{-1} \mathrm{DM}$. At the same time, diets with higher energy densities allow the production of heavier carcasses with higher yields.

\section{References}

Alves, K. S., Carvalho, F. F. R., Ferreira, M. A., Véras, A. S. C., Medeiros, A. N., Nascimento, J. F.,... Anjos, A. V. A. (2003). Teores de energia em dietas para ovinos Santa Inês: características de carcaça e constituintes corporais. Revista Brasileira de Zootecnia, 32(6), 1927-1936. doi: 10.1590/S151635982003000800017

Araújo, T. L. A. C., Pereira, E. S., Mizubuti, I. Y., Campos, A. C. N., Pereira, M. W. F., Heinzen, E. L.,... Oliveira, R. L. (2017). Effects of quantitative feed restrictionand sex on carcass traits, meat quality and meat lipid profile of Morada Nova lambs. Journal of Animal Science and Biotechnology, 8(46), 1-12. doi: 10.1186/s40104-017-0175-3

Cartaxo, F. Q., Sousa, W. H., Costa, R. G., Cezar, M. F., Pereira, J. M., Fo., \& Cunha, M. G. G. (2011). Características quantitativas da carcaça de cordeiros de diferentes genótipos submetidos a duas dietas. Revista Brasileira de Zootecnia, 40(10), 2220-2227. doi: 10.1590/s1519-99402017000200017

Chamkaur, A., Nishida, T., Phosphasal, I., \& Sommart, K. (2015). Effects of feeding level on methane emissions and energy utilization of Brahman cattle in the tropics. Agriculture, Ecosystems \& Environment, 199(1), 225-230. doi: 10.1016/j.agee.2014.09.014 
Colomer-Rocher, F., Morand-Fehr, P., Kirton, A. W., Delfa-Belenguer, R., \& Sierra-Alfranca, I. (1988). Métodos normalizados para el estudio de los caracteres cuantitativos y cualitativos de las canales caprinas y ovinas. Madrid: INIA.

Constantino, C., Koritiaki, N. A., Fernandes, F., Jr., \& Ribeiro, E. L. A. (2018). Desempenho, qualidade da carcaça e carne de ovinos de descarte de diferentes idades e gêneros. PUBVET, 12(2), 1-9. doi: 10. 22256/pubvet.v12n2a34.1-9

Detmann, E., Gionbelli, M. P., \& Huhtanen, P. (2014). A meta-analytical evaluation of the regulation of voluntary intake in cattle fedtropical forage-based diets. Journal of Animal Science, 92(10), 4632-4641. doi: $10.2527 /$ jas.2014-7717

Furusho-Garcia, I. F. F., Pérez, J. R. O., Bonarurio, S., Lima, A. L., \& Quintão, F. A. (2004). Estudodos cortes da carcaça de cordeiros Santa Inês puros e cruzas Santa Inês com Texel, Ile de France e Bergamácia. Revista Brasileira de Zootecnia, 33(2), 453-462. doi: 10.1590/S1516-35982004000200024

Gonzaga, S., Neto, Silva, A. G., Sobrinho, Zeola, N. M. B. L., Marques, C. A. T., Silva, A. M. A., Pereira, J. M., Fo., \& Ferreira, A. C. D. (2006). Características quantitativas da carcaça de cordeiros deslanados Morada Nova em função da relação volumoso:concentrado na dieta. Revista Brasileira de Zootecnia, 35(4), 1487-1495. doi: 10.1590/ S1516-35982006000500031

Grandis, F. A., Ribeiro, E. L. A., Mizubuti, I. Y., Bumbieris, V. H., Jr., Prado, O. P. P., \& Pinto, A. P. (2016). Características de carcaça e qualidade da carne de cordeiros alimentados com diferentes teores de torta de soja em substituição ao farelo de soja. Ciência Animal Brasileira, 17(3), 327-341. doi: 10. 1590/1089-6891v17i330941

Kearl, L. C. (1982). Nutrients requeriments of ruminants in developing countries. Logan, UT: International Feedstuffs Institute.

Mahgoub, O., Lu, C. D., \& Early, R. J. (2000). Effects of dietary energy density on feed intake, body weight gain and carcass chemical composition of Omani growing lambs. Small Ruminant Research, 37(1), 35-42. doi: 10.1016/S0921-4488(99)00132-7

Mattos, C. W., Carvalho, F. F. R. C., Dutra, W. M., Jr., Véras, A. S. C., Batista, A. M. V., Alves, K. S.,... Miranda, S. B. (2006). Características de carcaça e dos componentes não-carcaça de cabritos Moxotó e Canindé submetidos a dois níveis de alimentação. Revista Brasileira de Zootecnia, 35(5), 2125-2134. doi: $10.1590 / \mathrm{S} 1516-35982006000700033$
Maysonnave, G. S., Campara, J. M., Vaz, F. N., Pascoal, L. L., Mello, R. O., Vargas, F. V., \& Pacheco, P. S. (2017). Estudo exploratório da precificação dos cortes ovinos comercializados em mercados online em diferentes países. Archivos de Zootecnia, 66(255), 405-413. doi: 10.21071/az.v66i255.2517

National Research Council (2007). Nutrients requeriments of small ruminants. Washington, DC: National Academy Press.

Osório, J. C. S., Osório, M. T. M., Fernandes, A. R. M., \& Vargas, F. M., Jr. (2014). Produção e qualidade de carne ovina. In A. B. Selaive, \& J. C. S. Osório (Eds.), Produção de ovinos no Brasil (pp. 399-445). São Paulo, SP: Roca.

Pereira, E. S., Pimentel, P. G., Fontenele, R. M., Medeiros, A. N., Regadas, J. G. L., Fº, \& Villarroel, A. B. S. (2010). Características e rendimentos de carcaça e de cortes em ovinos Santa Inês, alimentados com diferentes concentrações de energia metabolizável. Revista Acta Scientiarum, 32(4), 431-437. doi: 10. 4025/actascianimsci.v32i4.9684

Piola, W., Jr., Ribeiro, E. L. A., Mizubuti, I. Y., Silva, L. D. F., Rocha, M. A., Barbosa, M. A.,... Paiva, F. H. P. (2009a). Ganho de peso e características da carcaça de cordeiros recebendo diferentes níveis de energia na ração. Semina: Ciências Agrárias, 30(4), 935944. doi: 10.5433/1679-03592009v30n4p935

Piola, W., Jr., Ribeiro, E. L. A., Mizubuti, I. Y., Silva, L. D. F., Sousa, C. L., \& Paiva, F. H. P. (2009b). Níveis de energia na alimentação de cordeiros em confinamento e composição regional e tecidual das carcaças. Revista Brasileira de Zootecnia, 38(9), 1797-1802. doi: 10.1590/S1516-35982009000900023

Puppel, K., \& Kuczynska, B. (2016). Metabolic profiles of cow's blood; a review. Journal of the Science of Food and Agriculture, 96(13), 4321-4328. doi: 10.1002/jsfa.7779

Ribeiro, E. L. A., Oliveira, H. C., Castro, F. A. B., Mizubuti, I. Y., Silva, L. D. F., \& Barbosa, M. A. A. F. (2010). Características de carcaça e carne de cordeiros mestiços de três grupos genéticos. Semina: Ciências Agrárias, 31(3), 793-802. doi: 10.5433/1679-0359.2010v31n3p793

Silva, D. J., \& Queiroz, C. (2002). Análise de alimentos (métodos químicos e biológicos). Viçosa, MG: Universidade Federal de Viçosa.

Silva, L. F., Pires, C. C., Zeppenfeld, C. C., \& Chagas, G. C. (2000). Crescimento de regiões da carcaça de cordeiros abatidos com diferentes pesos. Ciência Rural, 30(3), 481-484. doi: 10.1590/S010384782000000300018 
Statistical Analysis System Institute (2016). SAS® Studio. User's guide (version 3. 5). Cary, NC: SAS Institute Inc.
Van Soest, P. J. (1965). Symposium on factors influencing the voluntary intake in relation to chemical composition and digestibility. Journal of Animal Science, 24(3), 834-843. doi: 10.2527/jas 1965. $243834 x$ 